\title{
Role of Holocene beds of the stout razor clam Tagelus plebeius in structuring present benthic communities
}

\author{
Jorge Gutiérrez*, Oscar Iribarne \\ Depå iamenio ùe ṡoılogı (rLeyN), Universidad Nacional de Mar del Plata, CC 573 Correo Argentino Central, \\ (7600) Mar del Plata, Argentina
}

\begin{abstract}
Shell beds of the stout razor clam Tagelus plebeius in life position are common in the intertidal areas of several SW Atlantic estuaries $\left(36^{\circ}\right.$ to $\left.39^{\circ} \mathrm{S}\right)$. In this study we investigate the effect of this habitat structure on the benthic community, focusing on: (1) species which use this habitat as a refuge, (2) characteristics of the internal and external shell sediment and the abundance of macroinfauna and meiofauna in each one, (3) the effect of removing or introducing life-position shells on the abundance of macroinfaunal and meiofaunal organisms, (4) the effectiveness of shells as predator excluders and (5) sedimentary balance in shell beds and the role of superficial life-position shells. Eighteen macrofaunal species were encountered inhabiting the shell cavities; the amphipod Corophium insidiosum, the gastropod Heleobia australis and the polychaete Laeonereis acuta were the most abundant. Water and organic matter content were higher in the inner shell sediment than in the sediment sampled outside, but the distribution of phi-grain size values did not differ significantly between them. Except for nematodes, all the meiof aunal taxa and $C$. insidiosum showed higher abundance in the inner shell sediment. Removal of life-position shells in a shell bed negatively affected the abundance of $C$. insidiosum and the polychaete Heteromastus similis. Shell introduction in a mud flat had a positive effect on the abundance of almost all the taxa encountered. Two predator exclusion experiments indicate that these shells protect the fauna living within the shells and the underlying shell infauna from motile surface predators. Observations of shorebird feeding behavior showed that they rarely peck into the shell cavities. Daily measurements of the protruding length of shells demonstrated that these beds are exposed to erosive regimes, and shell removal in a shell assemblage destabilizes the sediment. The evidence suggests that superficial shells positively affect the diversity and abundance of organisms.
\end{abstract}

KEY WORDS: Habitat structure Shell beds - Physical ecosystem engineers - Positive effects Taphonomic feedback Benthos. Tagelus plebeius

\section{INTRODUCTION}

Trophic interactions and resource competition have been shown to be important forces in structuring communities (e.g. Connell 1961, Paine 1966). Nevertheless, many organisms control, directly or indirectly, the availability of resources to other organisms by changing the physical state of the biotic or abiotic materials (Jones et al. 1997). These habitat-modifying organisms, called 'physical ecosystem engineers' or 'bio-

•E-mail: jlgutie@mdp.edu.ar engineers' (sensu Jones et al. 1994), play an important role in determining the structure and functioning of most ecosystems (Jones et al. 1994, 1997, Lawton \& Jones 1995). Physical ecosystem engineering by organisms is the physical modification, maintenance or creation of habitats, and in all cases involves changes from one physical state or condition to another (Jones et al. 1997). The ecological effects of engineering on other species occurs, because the physical state changes directly or indirectly control the resources used by these other species, although not all the changes have important ecological consequences (Jones et al. 1997). 
The production of hard pieces (such as shells or tubes) is one of the ways in which benthic organisms can modify soft-bottom habitats (Day et al. 1989). When these structures accumulate on the sediment surface, the physical processes that affect the substrata can be extensively modified. High densities of mollusk shells form a matrix that increases the resistance to erosion, and oyster and mussel reefs (as extreme examples of shell beds) can trap suspended sediments and increase deposition rates (Rhoads et al. 1978). Artificial beds of oyster shells reduce erosion and vegetation loss in intertidal salt marshes (Meyer et al. 1997). In addition, shells or oyster beds may have important effects on the benthic community. Oysters are 'physical ecosystem engineers' by creating reef habitats and by controlling the availability of refuges to other organisms (Lenihan \& Peterson 1998). The presence of oyster shells in soft-sediment habitats enhances the densities of infauna (Dauer et al. 1982). Artificial shell habitats increase recruitment of the economically important Dungeness crab Cancer magister (Dumbauld et al. 1993) and enhance the density of many other benthic organisms (Iribarne et al. 1992).

Substrate protruding structures may enhance the abundance and diversity of organisms through different processes. Planktonic larvae may act like passive particles in turbulent near-bottom flows (Hannan 1984), and the modification of the hydrodynamic environment near the bed caused by the presence of protruding structures promotes high levels of larval recruitment (Eckman 1983). Moreover, active habitat selection by larvae may determine the pattern of adult distribution (e.g. Woodin 1985, Butman 1987), and many larvae of benthic organisms actively select structurally complex habitats (Botero \& Atema 1982, Hernkind \& Butler 1986, Fernandez et al. 1993, 1994). The habitat structuring elements may also serve as obstacles for predator activities (Woodin 1981, Peterson 1982) and act to minimize the injurious effects of the different sources of disturbance or environmental extremes (Kneib 1984, Safriel \& Ben-Eliahu 1991). Differential survival after settlement has been proposed as a key factor in determining the distribution pattern of adult benthic invertebrates (e.g. Peterson 1979, 1986, Fernandez et al. 1993).

The stout razor clam Tagelus plebeius (Veneroida: Solecurtidae) is an euryhaline species which inhabits tidal flat areas with cohesive sandy silt sediments (Holland \& Dean 1977a,b). Extant populations are currently distributed on the west Atlantic coast estuarine environments from North Carolina $\left(34^{\circ} \mathrm{N}\right.$, USA; Holland \& Dean $1977 \mathrm{a}, \mathrm{b})$ to the San Matías Gulf $\left(41^{\circ} \mathrm{S}\right.$, Argentina; Iribarne \& Botto 1998). They are found from $30 \mathrm{~cm}$ below mean low water (MLW) to $90 \mathrm{~cm}$ above MLW and their density has been shown to range from
200 clams $\mathrm{m}^{-2}$ just above MLW to $<5 \mathrm{clams}^{-2}$ at 50 to $90 \mathrm{~cm}$ above MLW (Holland \& Dean 1977a,b). A horizon with $T$. plebeius shells showing articulated and life-position valves occurs in Holocene tidal flat sediments of regional estuarine environments (e.g. Fasano et al. 1982, Schnack et al. 1982, Aliotta \& Farinatti 1990) from the mouth of La Plata River (Bahia Samborombón, $36^{\circ} 22^{\prime} \mathrm{S}, 56^{\circ} 45^{\prime} \mathrm{W}$ ) to Bahía San Blas $\left(39^{\circ} 25^{\prime} \mathrm{S}, 62^{\circ} 25^{\prime} \mathrm{W}\right.$; lsla \& Rivero D'Andrea 1993 ; Fig. 1A). Radiocarbon dating of shells of some of these beds revealed ages ranging between $3850 \pm 60$ and $1340 \pm 50$ before present (Fasano et al, 1982 , Schnack et al. 1982). The presence of these shells was commonly attributed to mass mortality phenomena (Schnack et al. 1982, Farinatti et al. 1992, Isla \& Rivero D'Andrea 1993), but there is strong evidence that they are the result of gradua: and continuous predation by the American oystercatcher Haematopus palliatus (Iribarne et al. 1998).

Erosion in recent years in several estuarine environments (e.g. Bahía Samborombón, Mar Chiquita coastal lagoon, Bahía Blanca, Bahía San Blas; Fig, 1A) has resulted in large intertidal areas covered with lifeposition shells protruding from the sediment (Fig. 2A). A characteristic of these clams is that their elongated round-ended shell (which can attain $90 \mathrm{~mm}$ total length) gapes at both ends to permit the protrusion of siphons and foot. When exposed, the shell cavities are filled with sediment and these upper and lower apertures allow the access of different benthic organisms to the internal cavity of the shells (Fig 2B). In this study we hypothesize that razor clam mortality and the subsequent erosion and exposure of the shells generate a habitat structure which is affecting the benthic community by providing living space, refuge and control over abiotic forces. We evaluate this hypothesis by investigating the following questions: (1) Which species use this habitat as a refuge? (2) Are there differences in the abundance of macroinfaunal and meiofaunal organisms, sediment granulometry and organic matter content between the internal and external shell sediment? (3) What is the effect of superficial shell removal or introduction on the abundance of macroinfaunal and meiofaunal organisms? (4) What is the effectiveness of these shells in excluding surface predators? and (5) What is the sedimentary balance in shell beds, and how is it affected by superficial lifeposition shells?

\section{METHODS}

Study area. This study was carried out in the Mar Chiquita coastal lagoon (Argentina, $37^{\circ} 32^{\prime}$ to $37^{\circ} 45^{\prime} \mathrm{S}$, $57^{\circ} 19^{\prime}$ to $57^{\circ} 26^{\prime} W_{i}$ Fig. 1A,B) from spring 1995 to 


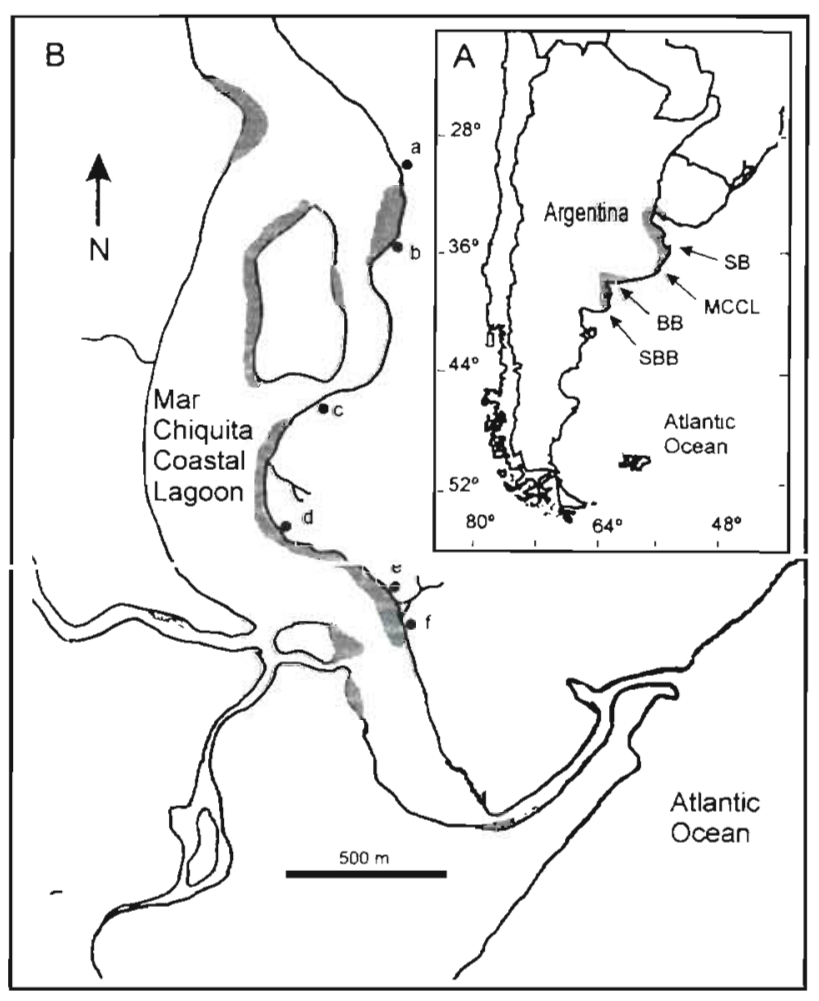

Fig. 1. (A) Location of the Mar Chiquita coastal lagoon and other SW Atlantic estuarine environments where superficial assemblages of life-position Tagelus plebeius shells are observed. Shaded areas indicate the distribution of the Holocene life-position razor clam shell horizon. Arrows mark localities where superficial assemblages are observed. SB: Bahía Samborombón, MCCL: Mar Chiquita coastal lagoon, BB: Bahía Blanca, SBB: Bahía San Blas. (B) Detail of the southern area of the Mar Chiquita coastal lagoon showing study sites (a, b, c, $d, e$ and f) and location of shell assemblages in the lagoon (shaded area)

autumn 1997. This is a body of brackish water which covers an area of $46 \mathrm{~km}^{2}$ (Fasano et al. 1982) and is affected by low amplitude ( $<1 \mathrm{~m}$ ) tides (Lanfredi et al. 1987). Intertidal environments at the lagoon comprise mud flats and large surrounding cordgrass Spartina densiflora areas (Olivier et al. 1972a, Iribarne et al. 1997). Superficial and exposed life-position razor clam shell beds are common in several intertidal environments near the mouth of the lagoon, often covering extensive intertidal areas. Study sites and locations of superficial assemblages are shown in Fig. $1 \mathrm{~B}$. Samplings and experiments were conducted at Site d and/or $50 \mathrm{~cm}$ above mean lower low water (MLLW) except for those cases where indicated.

Razor clam shell density at the study site. A random sampling was conducted in an intertidal shell bed to determine the density and the percentage of area covered by protruding life-position shells and loose valves or fragments at the sediment surface. Thirty samples were taken using a $0.25 \mathrm{~m}^{2}$ square sampling unit and all shells in life position, visible at the surface, were counted. The loose valves and fragments bigger than $1 \mathrm{~cm}^{2}$ found at the substrata surface were also determined to species and counted. Twelve protruding lifeposition shells from 10 of the sampling units were randomly taken and their major and minor diameter at the substrate level were measured. Elsewhere, 12 Tagelus plebeius loose valves or fragments bigger than $1 \mathrm{~cm}^{2}$ and all loose shells or fragments corresponding to other species were collected from the same 10 sampling units and carried to the laboratory. Total area of razor clam habitat was then calculated as follows: the

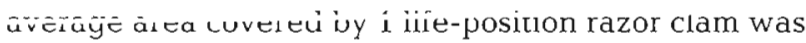
assessed by calculating the surface area of an ellipsoid. The average area covered by each loose shell was estimated by drawing its contour in squared paper (square size $0.25 \mathrm{~cm}^{2}$ ) and counting the number of complete squares included in this area. The area of the remaining square fractions was calculated by squaring them in smaller quadrates $\left(0.01 \mathrm{~cm}^{2}\right)$. Using the above observations we developed a computer iterative resampling procedure to estimate the total area covered by lifeposition and loose shells. The following equation describes the model:

$$
\begin{aligned}
\text { Area }= & \text { average number of shells } \mathrm{m}^{-2} \times \text { average } \\
& \text { area covered per shell }
\end{aligned}
$$

A resampling technique (Manly 1992) was used to randomly select values from a normal distribution of each variable (i.e. density of shells and area covered per shell) with mean and variance fixed at their estimated values. The median and a confidence level of $95 \%$ for the estimates were obtained from the distribution that resulted from 10000 iterative replications, which allowed confidence limits of $10 \%$ around the mean estimation. This technique permitted us to obtain the average area covered by shells without neglecting the variance of the multiplied variables.

Organisms that shelter in razor clam shells. To determine which macrofaunal organisms use these shells as refuge, samples of clams were obtained bimonthly between July 1996 and September 1997. Each sample was obtained according to the following scheme: three $20 \mathrm{~m}$ transects were demarked and 10 shells were randomly taken at the MLLW, $0.5 \mathrm{~m}$ and $0.8 \mathrm{~m}$ above MLLW. The epifaunal organisms were directly extracted, determined and counted. Crab carapace width (CW) was also measured. The inner shell sediment was sieved through a $500 \mu \mathrm{m}$ screen to obtain the macroinfauna. Abundances were calculated as the number of individuals per shell. The possibility of positive or negative association between pairs of the 8 most abundant macroinfaunal species occupying the shell cavities was tested with a chi-square test of inde- 


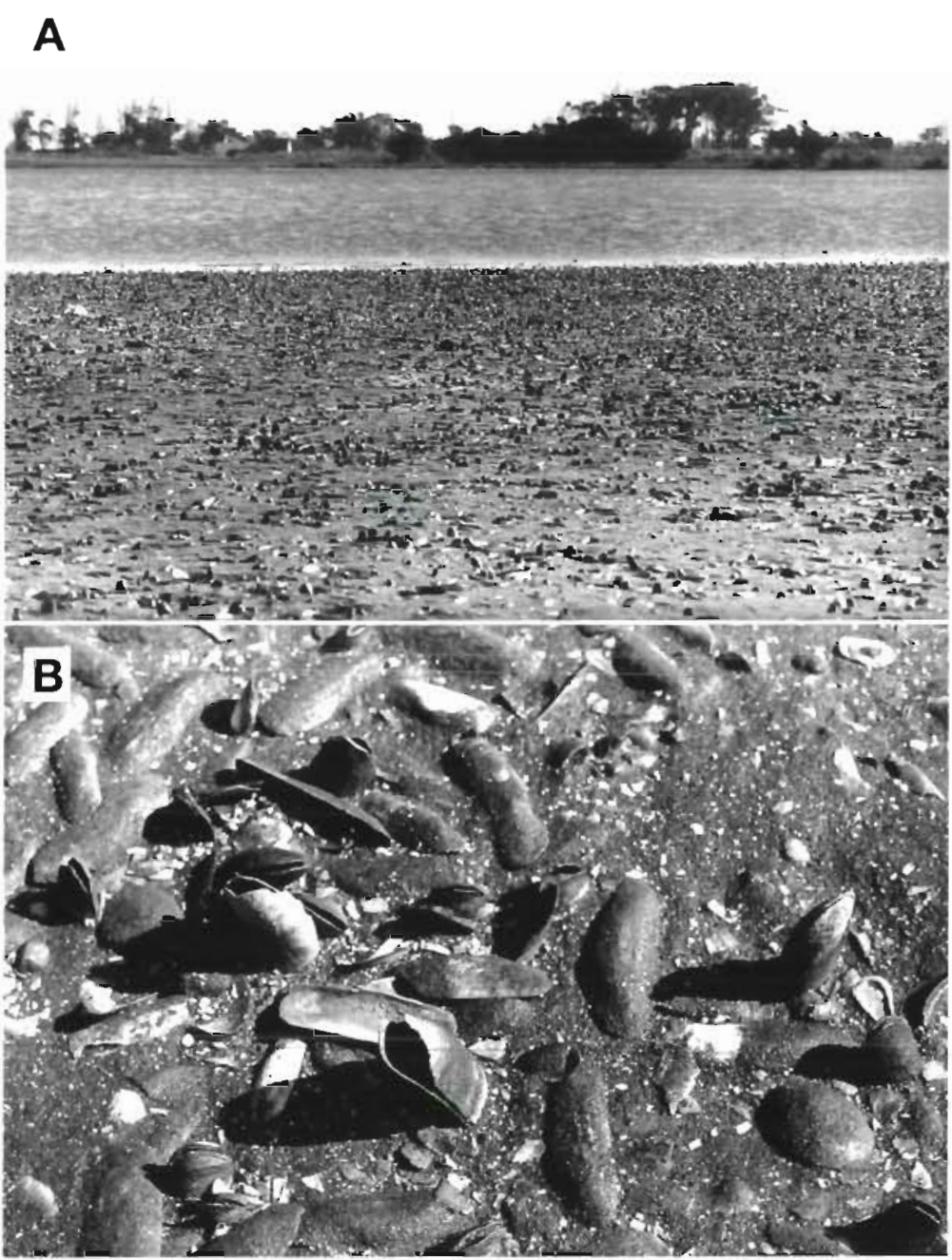

Fig. 2. (A) Extensive intertidal area covered by superficial life-position Tagelus plebeius shells at the Mar Chiquita coastal lagoon (Site d, see Fig. 1B). (B) Detail of life-position shells showing the upper aperture and internal cavity. The area shown in the photograph has approximate dimensions of $30 \times 20 \mathrm{~cm}$. Photographed by María Sampedro
Ten shells (inside-shell sediment; ISS) and ten $20 \mathrm{~cm}^{2}$ (outside-shell sediment; OSS) core samples $(3 \mathrm{~cm}$ depth, which is the equivalent to mean shell burial depth) were collected for water and organic content determination. A single sample from each ISS and OSS was used for granulometric analysis. Each one consisted of the pooled sediment of 6 shells (ISS sample) and the pool of three $20 \mathrm{~cm}^{2}$ ( $3 \mathrm{~cm}$ depth) core samples (OSS sample). This core size is not large enough such that large shells or shell fragments fit inside, and, thus, allows us to compare grain-size distribution within the range of grain sizes occurring inside the shells. A Smirnov test (Conover 1980) was used to compare the distribution of phi values between the ISS and the OSS. Median grain sizes and the inclusive graphic standard deviation (IGSD) as a sorting coefficient were calculated for the ISS and the OSS following Gray (1981). The null hypothesis of no difference in the percentage of water and organic content between the ISS and the OSS was contrasted with a $t$-test (Zar 1984). Proportional data were arcsine square-root transformed to attain the assumption of normality (Zar 1984).

Abundances of macroinfauna and meiofauna: Random samplings were performed in a shell bed in February 1996 to compare the abundance of macroinfaunal and meiofaunal organisms in the sediment inside and outside razor clam shells. Both macroinfaunal and meiofaunal samplings consisted of 10 ISS samples and 10 OSS samples. For macroinfauna, each ISS sample consisted of the pooled internal sediment of all the surfacing life-

pendence for the corresponding $2 \times 2$ contingency tables (Zar 1984), and the degree of association between species was measured using the Ochiai index (OI; Ludwig \& Reynolds 1988).

Comparison between the internal and external shell environment. Sediment characteristics: For granulometric analysis, sediment samples were wet-sieved through a series of screens with 6 different mesh openings from 2000 to $62 \mu \mathrm{m}$ and mesh size was expressed according to the phi scale (Gray 1981). Water content of samples was determined by calculating the difference between the wet and dry weight after drying the samples for $72 \mathrm{~h}$ at $70^{\circ} \mathrm{C}$. Organic matter content of the sediment was determined as the percentage of the ash-free dry weight of sediment following Crisp (1971) position shells in a square area of $0.36 \mathrm{~m}^{2}$. Sediment core samples of $1750 \mathrm{~cm}^{3}$ ( $20 \mathrm{~cm}$ depth) were collected from the same areas after the removal of all superficia] shells (OSS sample). Each core sample was divided into 2 layers: the upper $3 \mathrm{~cm}$ (depth comparable to that of the ISS) and the lower $17 \mathrm{~cm}$. For meiofauna, ISS and OSS samples were taken independently. Each ISS sample consisted of the sediment of a single shell, whereas each OSS sample was taken with a $20 \mathrm{~cm}^{3}$ core ( $3 \mathrm{~cm}$ depth). Macroinfauna was obtained by sieving the sediment through a $500 \mu \mathrm{m}$ mesh. In the case of meiofauna, the sediment was sieved through a $100 \mu \mathrm{m}$ mesh and the retained sediment observed with a $25 x$ binocular microscope. All the macroinfaunal and meiofaunal organisms obtained were identified and counted. 
In both cases the inner shell sediment volume was estimated by water displacement. Organism abundance was quantified as the number of individuals per unit of volume of sediment. The null hypothesis of no difference in the densities of each macroinfaunal species between the 3 sediment origins was evaluated with the Quade test ( $T$, Conover 1980). A t-test (Zar 1984) was used to test for differences in the densities of the meiofaunal taxa, between the internal and external shell sediment. A Mann-Whitney test (Conover 1980) was employed when the assumptions of normality and/or homoscedasticity were violated.

Effect of razor clam shells on the benthic community. Removal of superficial shells: An experiment was performed from November 1995 to June 1996 in a shell bed to evaluate the effect of life-position shell removal on the macroinfaunal and meiofaunal abundances. This experiment consisted of 3 treatments ( 5 replicates each): (1) removal of superficial shells, (2) removal and reintroduction of shells in the same site (control for experimental manipulation) and (3) areas not disturbed as controls. An additional shell-removal unit was deployed in order to test the effect of shell removal on the sediment granulometry after $1 \mathrm{wk}$. All experimental units had a $0.36 \mathrm{~m}^{2}$ area. In the removal treatments, the holes left in the substrata by the shell extractions were filled with the inner shell sediments. A $875 \mathrm{~cm}^{3}$ core $(10 \mathrm{~cm}$ depth) was used to sample the macroinfauna and a $6 \mathrm{~cm}^{3}$ core $(3 \mathrm{~cm}$ depth) was used in the case of meiofauna. Three core samples of $20 \mathrm{~cm}^{3}$ ( $3 \mathrm{~cm}$ depth) were taken both from the additional shellremoval unit and the adjacent undisturbed shell bed area. All samples were processed as in the previous cases. The null hypothesis of no difference in the abundance of each macroinfaunal species and meiofaunal taxa between treatments was contrasted with an ANOVA test (Zar 1984). A Kruskal-Wallis test (Conover 1980) was used when the assumptions of ANOVA were not met. A Smirnov test (Conover 1980) was employed to test the null hypothesis of no difference in the distribution of phi values between the sediment of the shell-removal unit and those of the undisturbed shell bed. Median grain sizes and the IGSD sorting coefficient (Gray 1981) were also calculated.

Introduction of superficial shell: To test the effect of the experimental introduction of life-position shells in a mud flat without burrows and protruding elements, 30 shells were driven into the sediment of randomly selected $0.25 \mathrm{~m}^{2}$ areas, and equal-sized units were used as controls. Twenty areas where shells were introduced and 10 controls were installed, half of the treatment units were used for the sampling of the internal shell sediment and the other half for surrounding shell sediment (inside-shell sediment sampling units [ISU] and outside-shell sediment sampling units [OSU] respectively; 10 replicates each). The objective of this design was to obtain the internal and external shell sediment of treatment areas as independent samples. The shells employed were subfossils obtained from an adjacent supralittoral buried assemblage. This prevented any effects of previously settled larvae in intertidal shells. This experiment was performed during January 1997, in the high intertidal area of a protected bay (Site a, Fig. 1B) to minimize the erosion induced by the shells in the surrounding sediment. Concurrently, an intense recruitment of the southwestern Atlantic fiddler crab Uca uruguayensis was observed. Macroinfaunal samples from the treatment and control units

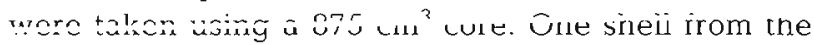
ISU and $6 \mathrm{~cm}^{3}$ sediment samples ( $3 \mathrm{~cm}$ depth) from the OSU and controls were taken for meiofaunal analysis. The remaining shells of the ISU and $875 \mathrm{~cm}^{3}(10 \mathrm{~cm}$ depth) core samples from the OSU and controls were taken in the case of macroinfauna. Shell sediment volume was estimated as in the previous case. The number of burrows of recently settled fiddler crabs in control areas, inside the ISU shells and in the OSU shells surrounding area, were counted. Shell major and minor diameters at the substrata level were measured to estimate the area covered per clam by calculating the surface area of an ellipse and, consequently, obtaining the total area covered (and uncovered) by shells in the shell sampling units. An ANOVA test (Zar 1984) was used to test for differences in the density of the different meiofaunal taxa and macroinfaunal species between the inner shell sediment, the surrounding shell sediment and the sediment from control units. A Kruskal-Wallis test (Conover 1980) was used when the ANOVA assumptions were violated. The null hypothesis of no difference in the number of burrows of fiddler crabs per unit of area between the shell-covered surface, the surrounding shell area and the controls was tested with a Kruskal-Wallis test (Conover 1980).

Effectiveness of razor clam shells as shelter. Predator exclusion experiments: To test the possibility that clams can protect the macroinfauna from surface predators, 2 predator exclusion experiments were performed in Tagelus plebeius shell patches of an intertidal area that is a common shorebird foraging site (Botto et al. 1998; Site b. Fig. 1B). Other large mobile organisms occurring at this site are the grapsid crabs Cyrtograpsus angulatus and Chasmagnathus granulata. These crabs are deposit-feeding species (Olivier et al. 1972b. Iribarne et al. 1997) which at shell beds feed on the sediment surface without burrowing, causing little sediment disturbance (pers. obs.). Although flounders Paralichthys orbignyanus, black drums Pogonias cromis and croakers Micropogonias furnieri are known as benthic predators (Olivier et al. 1972b), there is no information about their occurrence in shallow 
intertidal areas during tidal inundation. This suggests that a possible effect of predation exclusion on the density of macrobenthic organisms must be mainly caused by shorebird predation (see Botto et al. 1998) and possibly fishes. Nine square wire mesh cages $\left(0.36 \mathrm{~m}^{2}\right.$ surface, $1.2 \mathrm{~cm}$ screen size) were installed from late February to May 1996, and 8 similar ones during January and February 1997. Control areas were randomly assigned at the end of each experiment. Ten shells and a $875 \mathrm{~cm}^{3}(10 \mathrm{~cm}$ depth) core sample were collected from each unit. All surfacing life-position shells included in the core samples were removed. A t-test (Zar 1984) was used to evaluate the hypothesis of no difference in the number of individuals per species in the core samples and clam sediment between treatments. A Mann-Whitney test (Conover 1980) was used in those cases where the normality and/or homoscedasticity assumptions were violated.

Shorebird feeding behavior in shell beds: Shorebirds were monitored during March and April 1997 to determine if they were capable of feeding in the shell cavities by introducing their bills. A total of $2 \mathrm{~h}$ of individual bird observations were conducted using $8 \times$ 40 binoculars. Each observation consisted of monitoring a single bird and counting the total number of picks inside and outside of the shell cavities for $2 \mathrm{~min}$. All the shorebirds observed in the study area at the moment of our arrival were determined and counted. A total of 11 censuses were performed. Shorebird determination was accomplished following Narosky \& Izurieta (1993). Due to the impossibility of monitoring this behavior in relation to the shells that remain underwater, observations were directed only to individuals of those shorebird species which feed on the intertidal exposed substrate. Pecking rates and the percent of pecks into the shell cavities were calculated for each species monitored. A chi-square test (Zar 1984) was used to evaluate if the frequency of probing inside shells differed from the frequency expected by random probing. The mean percentage of coverage by life-position shells was used as the expected proportion based on random probing.

Sedimentary processes in the shell beds. Rates of erosion: To determine the rates of erosion in the area immediately surrounding the superficial life-position shells, 10 shells were labeled on each of 2 different sites separated by approximately $50 \mathrm{~m}$ (Sites e and $\mathrm{f}$, Fig. 1B), and their protruding length (as an indicator of sediment level) was measured during 4 consecutive tidal cycles. The sites selected for these measurements were small patches with similar densities of protruding life-position shells, but different densities of loose shells which could be directly observed. Current velocities were measured daily on each site, approximately at the midpoint of the ebb tide. Five measures were taken each day by timing the flow of an ink marker over a known distance. A random sampling was performed to estimate densities of superficial life-position and loose shells (including fragments retained by $1 \mathrm{~cm}$ mesh) at the 2 sites using $0.09 \mathrm{~m}^{2}$ sampling units $(\mathrm{n}=10$ ). The null hypothesis of no differences in current velocities between sites was contrasted with a paired-sample ttest (Zar 1984). A t-test (Zar 1984) was used to test for differences in the densities of superficial life-position and loose shells between sites while a Mann-Whitney test (Conover 1980) was used to test for differences in the measurements of erosion between the 2 sites.

Superficial shell effect on sedimentary processes: To determine if superficial life-position shells induce erosion in the surrounding substrate, both shellremoval and introduction experiments were carried out. For the shell-removal experiment, six $4 \mathrm{~m}^{2}$ square areas were demarked in a shell bed (Site e, Fig. 1B) and all superficial life position shells encountered were removed. In the case of the shell introduction experiment, 5 square $0.16 \mathrm{~m}^{2}$ patches with 20 shells each were planted in a sandy intertidal area at the shore of a narrow channel. This channel shows an approximately unidirectional current whose course is determined by the inflow or outflow of water in the lagoon (Site c, Fig. 1B). Sediment levels on the experimental units were measured with a sliding ruler attached to a $1 \mathrm{~m}$ horizontal iron rod which was supported by two $30 \mathrm{~cm}$ vertical pivots separated $1 \mathrm{~m}$ apart and driven into the sediment to a depth of $15 \mathrm{~cm}$. The horizontal rod was placed over the pivots only at the moment of measurement and was levelled previously to the first measurement with a spirit level. The pivots were not removed during the experimental period but were arranged over an imaginary line perpendicular to the main current direction to minimize the hydrodynamic disturbance that may be caused by these protruding structures on the experimental areas. The initial sediment height and the height at the end of the experimental period (shell removal experiment: $10 \mathrm{~d}$, shell introduction experiment: 3 d) were measured in the treatment patches and in 5 undisturbed control areas. Current velocities at Site $\mathrm{c}$ were measured as in the previous case. The null hypothesis of no difference in the height of sediment eroded between treatment and control areas was analyzed with a Mann-Whitney test (Conover 1980).

Evaluation of test assumptions. Normality of the data was checked using the Shapiro-Wilk test (Zar 1984) while homoscedasticity of the data was analyzed with the Levene's test (Underwood 1997). The Bartlett test (Zar 1984) was applied to test for homoscedasticity in the case of the measurements of sedimentary balance in the shell-removal experiment, because it can be used where sample sizes differ (Underwood 1997). 


\section{RESULTS}

\section{Razor clam shell density at the study site}

Life-position and loose Tagelus plebeius shells covered an average $29.37 \%(\mathrm{SD}=5.7)$ of the study area. Loose shells of Mactra isabelleana and Glycimeris longior were found at a lower density, covering only an average $3.02 \%(\mathrm{SD}=0.79)$ of the study area (Table 1$)$. Four other species were encountered at very low densities (Amiantis purpurata: $\bar{x}=0.86$ shells $\mathrm{m}^{-2}, \mathrm{SD}=$ 0.89; Olivella plata: $\bar{x}=0.68$ shells $\mathrm{m}^{-2}, \mathrm{SD}=0.94$; Ostrea sp: $\bar{x}=0.11$ shells $\mathrm{m}^{-2}, \mathrm{SD}=0.13$; and Adelomelon brasiliensis: $\bar{x}=0.04, \mathrm{SD}=0.07$ ) and were not considered in the coverage analysis.

\section{Organisms that shelter in razor clam shells}

Eighteen species were observed using the cavity of the shell as refuge but $80 \%$ of the individuals were accounted for by only 5 species (Table 2). Amphipoda was numerically the most important taxon inhabiting clams, but polychaetes were the group that showed the highest number of species (5 species). There were also 10 rare species, contributing only $4.5 \%$ of the total individuals sampled.

Six negative associations were encountered with respect to the use of shell cavities: Cyrtograpsus altimanus with Laeonereis acuta (chi-square test: $\mathrm{p}<0.01$; $\mathrm{OI}=0.063$ ), C. altimanus with Heleobia australis (chisquare test: $p<0.05 ;$ OI $=0.078)$, Corophium insidiosum with Melita palmata (chi-square test: $\mathrm{p}<0.05$; $\mathrm{OI}=0.113$ ) and no coexistence among crab species was encountered. No positive associations were found. The crabs collected correspond to juvenile stages in 2 of these cases (Cyrtograpsus angulatus: maximum $\mathrm{CW}$ $=13 \mathrm{~mm}$ and Chasmagnathus granulata: maximum $\mathrm{CW}=9 \mathrm{~mm}$ ). Maximum $\mathrm{CW}$ registered for the small sized crab C. altimanus was $11 \mathrm{~mm}$.

Table 1. Mean (SD) density, area covered per single shell and percent of total area covered for each shell species encountered at the study site

\begin{tabular}{|lcccc|}
\hline & $\begin{array}{c}\text { Density } \\
\text { (shells } \mathrm{m}^{-2} \text { ) }\end{array}$ & $\begin{array}{c}\text { Area covered } \\
\text { per shell }\left(\mathrm{cm}^{2}\right)\end{array}$ & $\begin{array}{c}\% \text { of } \\
\text { area }\end{array}$ \\
\hline $\begin{array}{l}\text { Life-position shells } \\
\text { Tagelus plebeius }\end{array}$ & $123.87(52.58)$ & $1.62(0.62)$ & $2(0.98)$ \\
Loose shells & & & & \\
Tagelus plebeius & $209.07(32.02)$ & $13.09(3.93)$ & $27.37(4.72)$ \\
$\begin{array}{l}\text { Mactra isabelleana } \\
\text { Glycimeris longior }\end{array}$ & $25.07(10.34)$ & $8.34(2.97)$ & 2.09 & $(0.32)$ \\
& $12.53(7.26)$ & $7.44(1.99)$ & 0.93 & $(0.47)$ \\
\hline
\end{tabular}

Table 2. Pooled abundance data for all the macrofaunal species encountered in the shell samples taken bimonthly from July 1996 to September 1997, with standard deviations and proportional numerical contribution of each species to the total number of individuals. Abundance is expressed as number of individuals per 100 shells. Percentages do not total 100 because of rounding errors. Key to taxa: B: Briozoa, CA: Amphipoda, CB: Brachyura, CC: Cirripedia, CI: Isopoda, MB: Bivalvia, MG: Gastropoda, N: Nemertea, P: Polychaeta

\begin{tabular}{|lcccc|}
\hline Species & Taxon & Mean & SD & $\begin{array}{c}\% \text { of } \\
\text { fauna }\end{array}$ \\
\hline Corophium insidiosum & CA & 107.07 & 83.01 & 38.43 \\
Helonhia alictralis & $\mathrm{A}$. & 30.05 & 20.55 & $13 . \overline{5}$ \\
Laeonereis acuta & $\mathrm{P}$ & 37.7 & 9.18 & 13.53 \\
Chasmagnathus granulata & $\mathrm{CB}$ & 21.3 & 13.68 & 7.64 \\
Cyrtograpsus angulatus & $\mathrm{CB}$ & 17.56 & 10.1 & 6.3 \\
Heteromastus similis & $\mathrm{P}$ & 15.66 & 15.3 & 5.62 \\
Cyrtograpsus altimanus & $\mathrm{CB}$ & 14.35 & 8.6 & 5.15 \\
Melita palmata & $\mathrm{CA}$ & 13.96 & 11.7 & 5.01 \\
Balanus improvisus & $\mathrm{CC}$ & 3.63 & 4.41 & 1.3 \\
Sphaeroma sp. & $\mathrm{Cl}$ & 3.14 & 3.75 & 1.13 \\
Neanthes succinea & $\mathrm{P}$ & 2.07 & 1.52 & 0.74 \\
Polydora ligni & $\mathrm{P}$ & 1.37 & 0.64 & 0.49 \\
Gorgonorhynchus sp. & $\mathrm{N}$ & 1.18 & 1.15 & 0.42 \\
Brachidontes rodriguezii & $\mathrm{MB}$ & 0.95 & 0.75 & 0.34 \\
Panopeus sp. & $\mathrm{CB}$ & 0.09 & 0.18 & 0.07 \\
Siphonaria lessoni & $\mathrm{MG}$ & 0.08 & 0.19 & 0.03 \\
Conopeum cf. seurati & $\mathrm{B}$ & 0.05 & 0.11 & 0.01 \\
Nephtys fluviatilis & $\mathrm{P}$ & 0.05 & 0.11 & 0.01 \\
& & & & \\
\hline
\end{tabular}

\section{Comparison between the internal and external shell environments}

\section{Sediment characteristics}

ISS and OSS showed similar grain-size characteristics (Table 3) and no significant differences were encountered when comparing their distribution of phi values (Smirnov test: $D$ max. $=3.45, k=7, \mathrm{n}=100, \mathrm{p}>$ 0.05 ; Table 3). Significantly higher water and organic matter content were encountered in the ISS than in the OSS (Table 4).

Table 3. Grain-size characteristics for the sediment inside (ISS) and outside (OSS) razor clam shells. The inclusive graphic standard deviation (IGSD) was used as sorting coefficient. "Moderately sorted sediment, " "poorly sorted sediment

\begin{tabular}{|lrr|}
\hline & \multicolumn{1}{c}{ ISS } & \multicolumn{1}{c|}{ OSS } \\
\hline Median grain size $(\mathrm{mm})$ & 0.25 & 0.27 \\
Silt-clay content $(\%)$ & 13.03 & 11.95 \\
Sorting coefficient & $0.9 \overrightarrow{7}^{\circ}$ & $1.16^{*}$ \\
\hline
\end{tabular}


Table 4. Mean (SD) percentage of water and organic matter for the sediment inside (ISS) and outside (OSS) razor clam shells and results of the t-tests $(\mathrm{df}=18)$

\begin{tabular}{|lcccc|}
\hline & ISS & OSS & $t$ & $p$ \\
\hline Water $(\%)$ & $24.90(1.67)$ & $23.20(1.35)$ & 2.47 & 0.023 \\
Organic matter $(\%)$ & $4.24(0.91)$ & $2.84(1.04)$ & 3.35 & 0.005 \\
\hline
\end{tabular}

\section{Abundance of macroinfauna and meiofauna}

Significant differences were found in the densities of 2 of the 3 macroinfaunal species encountered in the samples with respect to the 3 sediment origins considered, but only Corophium insidiosum showed significantly higher density in the shell sediment with respect to the other types of sediment (Quade test: $T=11.25, \mathrm{n}$ $=20, p<0.01$ ). Laeonereis acuta density was significantly lower in the sediment from the depth range between 3 and $20 \mathrm{~cm}$ with respect to the superficial $3 \mathrm{~cm}$ sediment and the inner shell sediment (Quade test: $T=4.45, \mathrm{n}=20, \mathrm{p}<0.01$ ), while Heteromastus similis showed no significant differences in its abundance between the 3 sediment origins (Quade test: $T=$ $11.2, n=20, p>0.05$; Fig. 3A). In the case of meio-

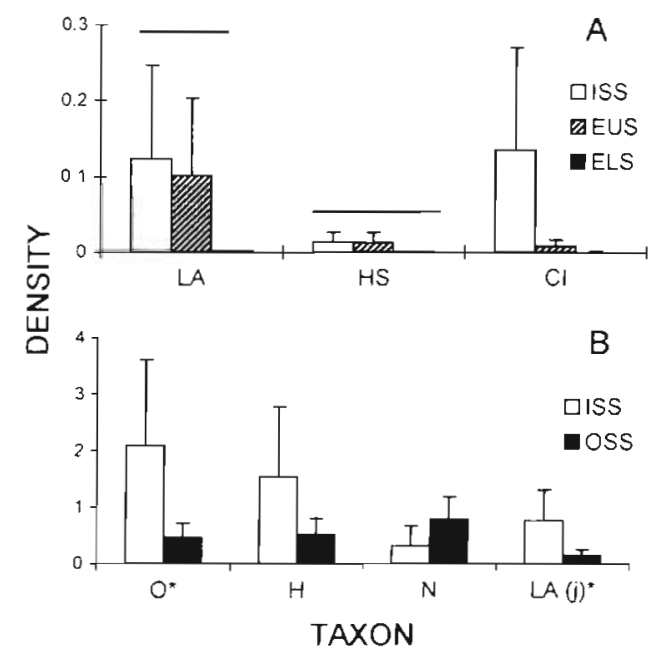

Fig. 3. (A) Mean densities of macroinfauna (ind. $\mathrm{cm}^{-3}$ ) corresponding to the 3 sediment origins (ISS: inside-shell sediment, EUS external shell sediment from the upper $3 \mathrm{~cm}$ layer and ELS: external shell sediment from the lower $17 \mathrm{~cm}$ layer) Horizontal lines indicate insignificant differences (Quade test - non-parametric multiple comparisons, $p>0.05$ ). LA: Laeonereis acuta; HS: Heteromastus similis; CI: Corophium insidiosum. (B) Mean densities $\pm 1 \mathrm{SD}$ of meiofauna (ind $\mathrm{cm}^{-3}$ ) encountered in the internal (ISS) and external (OSS) shell sediments. Horizontal lines indicates non significant differences $(t$-test, $p>0.05$ ). Mann-Whitney test. $O$ : Ostracoda H: Harpacticoidea; N: Nematoda; LA(j): juvenile Laeonereis acuta In both cases vertical lines above the bars represent 1 SD fauna, abundances in the internal and external clam sediments differed significantly in all the taxa encountered (Ostracoda: Mann-Whitney test, $Z=-3.17, \mathrm{n}=$ 20, $\mathrm{p}<0.01$; Harpacticoidea: $t$-test, $t=-2.75, \mathrm{df}=18$, $\mathrm{p}<0.05$; Nematoda: $t$-test, $t=-2.75, \mathrm{df}=18, \mathrm{p}<0.05$; juvenile L. acuta: Mann-Whitney test, $Z=-3.59, \mathrm{n}=20$, $p<0.01$ ). Except nematodes, the remaining taxa were most abundant in the internal shell sediment (Fig, 3B).

\section{Effect of razor clam shells on the benthic community}

$$
\text { Removal of superficial shells }
$$

Removal of life-position shells negatively affected the abundances of 2 of the 4 macroinfaunal species encountered at the end of the experiment (Fig, 4):
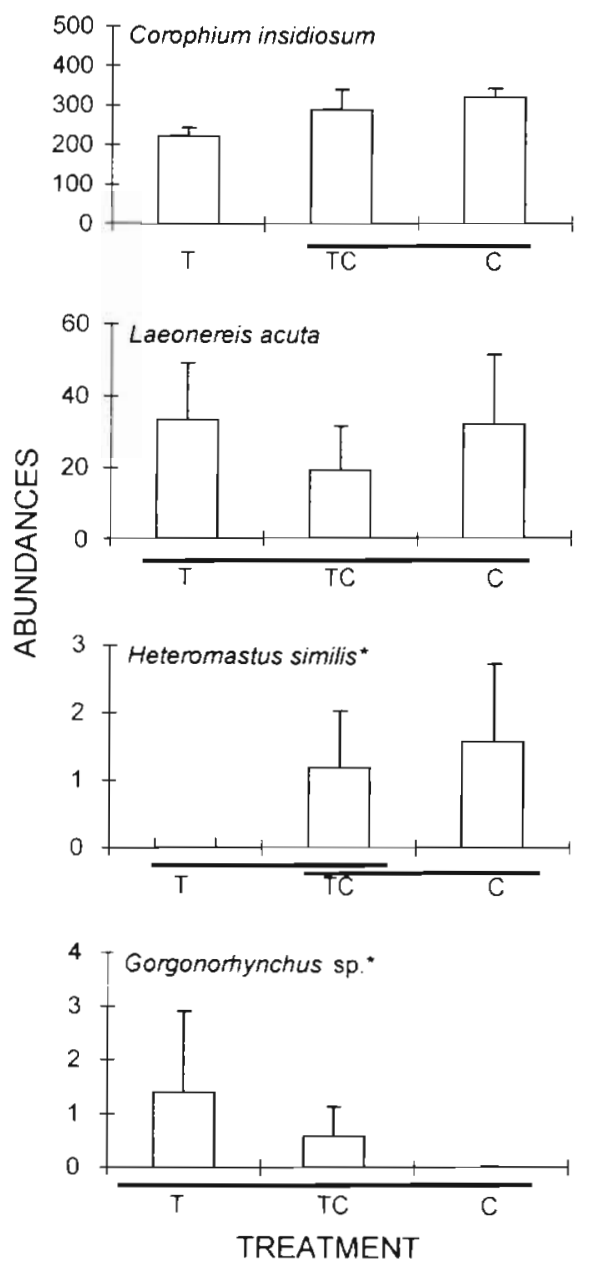

Fig. 4. Mean abundances of macroinfaunal species for the superficial shell-removal experiment. Vertical lines above the bars represent 1 SD. Columns underlined are not significantly different (ANOVA, Tukey test, $p>0.05$ ). "Kruskall-Wallis test - non-parametric multiple comparisons. $T$ : shells removed TC: shells removed and reintroduced; $C$ : undisturbed 
Corophium insidiosum (ANOVA: $F=11.25$, $\mathrm{df}=2, \mathrm{p}<0.01)$ and Heteromastus similis (Kruskal-Wallis test: $H=4.64, \mathrm{df}=2, \mathrm{p}<$ 0.05 ), and had no effect on the abundance of Laeonereis acuta (ANOVA: $F: 1.16, \mathrm{df}=2, \mathrm{p}$ > 0.05 ), Gorgonorhynchus sp. (Kruskal-Wallis test: $H=4.64, \mathrm{df}=2, \mathrm{p}>0.05$ ) and all the meiofaunal taxa (Ostracoda: ANOVA, $F=1.5$, $\mathrm{df}=2, \mathrm{p}>0.05$; Harpacticoidea: ANOVA: $F=0.37, \mathrm{df}=2, \mathrm{p}>0.05$; Nematoda: ANOVA: $F=0.43, \mathrm{df}=2, \mathrm{p}>0.05$ ). There were no observed effects of shell manipulation in any of the taxa analyzed. On the other hand, the distribution of phi values differed significantly between treatments (Smirnov test: $D \max .=19.61, k=7, \mathrm{n}=100, \mathrm{p}<0.05$; Fig. 5). The sediment of the treatment showed a larger median grain size $(0.43 \mathrm{~mm})$ than those of the control $(0.33 \mathrm{~mm})$ and lower silt-clay content ( 3.46 and $4.95 \%$ respectively). The sorting coefficients were similar in both samples (IGSD $=1.23$; poorly sorted sediment).

\section{Introduction of superficial shell}

The only macroinfaunal species encountered at the end of the experiment was the polychaete Laeonereis acuta, which showed significantly higher densities in the inner shell sediment than in the outside shell and control sediments (Kruskall-Wallis test: $H=24.67, \mathrm{n}=30, \mathrm{p}<$ 0.01 ). Similar results were encountered for 2 meiofaunal taxa (ostracods: Kruskall-Wallis test: $H=17.83, \mathrm{n}=$ 30, p < 0.01; nematods: Kruskall-Wallis test: $H=12.96$, $\mathrm{n}=30, \mathrm{p}<0.01$ ) while harpacticoid copepods showed higher densities in the inner shell and OSU sediment with respect to the controls (ANOVA: $F=3.98, \mathrm{df}=2$, $\mathrm{p}<0.05$ ), and juvenile $L$. acuta showed no significant differences (Kruskall-Wallis test: $H=0.52, \mathrm{n}=30$, $p>0.05$ ). The density of burrows of recently settled

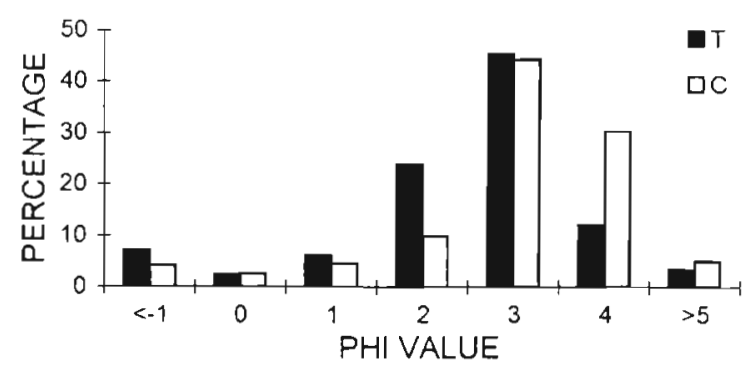

Fig. 5. Percentage distribution of phi grain-size values corresponding to areas where shells were removed $(\mathrm{T})$ and undisturbed (C). Smirnov test $p<0.05$
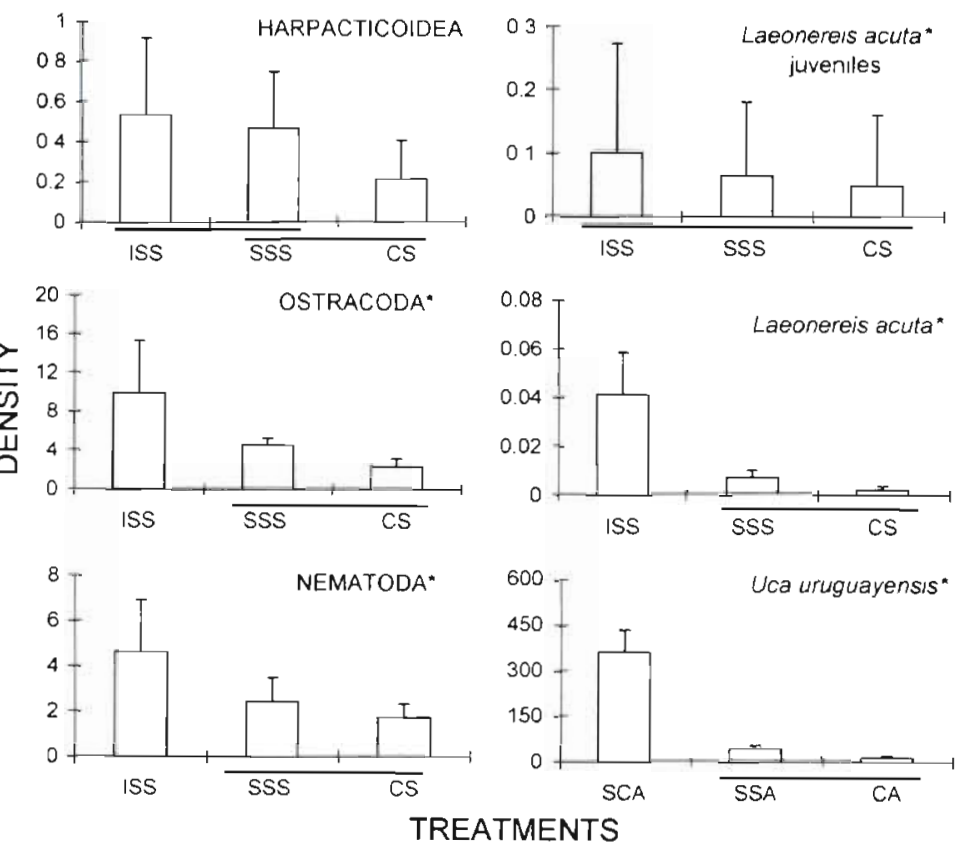

Fig. 6. Mean densities, expressed as ind $\mathrm{cm}^{-3}$ for macroinfauna and meiofauna, and burrows $\mathrm{m}^{-2}$ for Uca uruguayensis, for the superficial shell introduction experiment. Vertical lines above the bars represent 1 SD. Columns underlined are not significantly different (ANOVA; Tukey test, $p>0.05$ ). 'Kruskall-Wallis test - non-parametric multiple comparisons. ISS: inside-shell sediment; SSS: surrounding shell sediment; CS: control sediment; SCA: shell-covered area; SSA: surrounding shell area; CA: control area

Uca uruguayensis was also significantly higher inside shells when compared with the OSU and control units (Kruskall-Wallis test: $H=20.19, \mathrm{n}=30, \mathrm{p}<0.01$; Fig. 6 ).

\section{Effectiveness of razor clam shells as shelter}

\section{Predator exclusion experiment}

No significant differences were observed in the abundance of organisms that use shells as shelter and the underlying infauna between the predator exclusion cages and the control areas in the 1996 experiment, but a significantly higher abundance of Heteromastus similis was encountered in the underlying sediment of control areas with respect to those of the caged units in the 1997 experiment ( $t$-test: $t=-2.59$, $\mathrm{df}=14, \mathrm{p}<0.05 ;$ Table 5).

\section{Shorebird feeding behavior in shell assemblages}

Almost all shorebirds observed feeding in the intertidal exposed substrata of superficial shell assemblages belong to 2 species: the two-banded plover Charadrius 
Table 5. Mean densities (SD) of fauna and significances of the t-test for the predator exclusion experiments. Densities of inside shell macrofauna are expressed as number of individuals per 100 shells while densities of underlying shell macroinfauna are expressed as number of individuals per sample. " $p<0.05$

\begin{tabular}{|c|c|c|c|c|c|c|}
\hline Species & Cages & $\begin{array}{c}1996 \text { Expt } \\
\text { Control }\end{array}$ & $\mathrm{p}$ & Cages & $\begin{array}{l}1997 \text { Expt } \\
\text { Control }\end{array}$ & $\mathrm{p}$ \\
\hline \multicolumn{7}{|l|}{ Inside-shell macrofauna } \\
\hline Laeonereis acuta & $2.22(2.77)$ & $0.67(0.54)$ & $0.21^{\mathrm{a}}$ & $0.12(0.35)$ & $0.37(0.52)$ & $0.26^{\mathrm{d}}$ \\
\hline Neanthes succinea & - & - & - & $0.75(0.71)$ & $1.25(1.03)$ & 0.28 \\
\hline Heteromastus similis & $0.21(0.44)$ & $0.46(0.54)$ & $0.51^{\mathrm{a}}$ & - & - & - \\
\hline Corophium insidiosum & $0.43(0.55)$ & $1(1.14)$ & 0.07 & - & - & - \\
\hline Melita palmata & $3.85(2.86)$ & $3(1.58)$ & 0.59 & $2.12(2.53)$ & $1.12(1.12)$ & 0.32 \\
\hline Heleobia australis & $1.44(2.19)$ & $1.41(1.67)$ & 1 & $1(1.51)$ & $1(1.77)$ & 1 \\
\hline Chasmagnathus granulata & - & - & - & $0.87(1.46)$ & $0.12(0.35)$ & $0.21^{\mathrm{a}}$ \\
\hline Cyrtograpsus altimanus & $1.66(1.14)$ & $3(1.22)$ & 0.1 & $3.75(2.31)$ & $4.25(1.91)$ & 0.64 \\
\hline Cyrtograpsus angulatus & $2(1)$ & $1.41(1.67)$ & 0.51 & $2.5(2.33)$ & $3.37(0.74)$ & $0.17^{d}$ \\
\hline Balanus improvisus & - & - & - & $0.5(0.53)$ & $0.25(0.46)$ & 0.33 \\
\hline \multicolumn{7}{|l|}{ Outside-shell macroinfauna } \\
\hline Laeonereis acuta & $15.4(11.7)$ & $8.4(4.83)$ & $0.42^{\mathrm{a}}$ & $3.87(1.45)$ & $3.37(2.67)$ & 0.64 \\
\hline Neanthes succinea & - & - & - & $0.37(0.74)$ & $0.25(0.46)$ & 0.69 \\
\hline Heteromastus similis & $3.21(5.02)$ & $1.2(1.3)$ & $0.75^{a}$ & $1(1.31)$ & $2.75(1.39)$ & $0.02^{\circ}$ \\
\hline aMann-Whitney test & & & & & & \\
\hline
\end{tabular}

falklandicus $\left(\bar{x}=40.53, \mathrm{SD}=34.6\right.$ ind. $\left.\mathrm{d}^{-1}\right)$ and the white-rumped sandpiper Calidris fuscicollis $(\bar{x}=28.22$, $\mathrm{SD}=48.36$ ind $\mathrm{d}^{-1}$ ). Other species were observed in smaller numbers and/or feeding in water-covered areas of the intertidal such as, the lesser yellowlegs Tringa flavipes $\left(\bar{x}=4.82, \mathrm{SD}=2.66\right.$ ind. $\left.\mathrm{d}^{-1}\right)$, the greater yellowlegs T. melanoleuca $\left(\bar{x}=2.86, \mathrm{SD}=2.04\right.$ ind. $\left.\mathrm{d}^{-1}\right)$, the American oystercatcher Haematopus palliatus $(\bar{x}=3.96$, $\mathrm{SD}=3.11$ ind $\left.\mathrm{d}^{-1}\right)$, the common stilt Himantopus melanurus $\left(\bar{x}=1.72, \mathrm{SD}=1.81\right.$ ind. $\left.\mathrm{d}^{-1}\right)$ and the American golden plover Pluvialis dominica $(\bar{x}=0.38, \mathrm{SD}=1.06$ ind. $\mathrm{d}^{-1}$ ). Pecking rates observed were 21.67 picks $\mathrm{min}^{-1}$ $(\mathrm{SD}=11.41, \mathrm{n}=31)$ for $C$. falklandicus and 58.96 picks min $^{-1}(\mathrm{SD}=15.82, \mathrm{n}=28)$ for $C$. fuscicollis. C. falklandicus pecked into the shell cavities only on $0.52 \%$ of the occasions, while C. fuscicollis was never seen introducing its bill inside shells. The frequency of shorebird probing inside shells differed significantly from that expected by random probing both for $C$. falklandicus (chi-square test: $\chi^{2}=11.55, \mathrm{df}=1, \mathrm{p}<0.001$ ) and $C$. fuscicollis (chi-square test: $\chi^{2}=48.12, \mathrm{df}=1, \mathrm{p}<0.001$ ), which indicate that these birds avoid probing inside the cavity of the shells.

\section{Sedimentary processes in the shells bed}

\section{Rates of erosion}

No significant differences among sites were observed for current velocities and life-position shell density, while significant differences were encoun- tered in the density of loose shells and in the total erosion around life-position shells (Table 6). The major part of the total erosion registered during the measuring period occurred between the second and the third tidal cycle (Site e: $\bar{x}=83.67 \%, \mathrm{SD}=53.95$; Site $\mathrm{f}: \bar{x}=$ $80.58 \%, \mathrm{SD}=43.91$ of the total erosion). During this period a storm occurred and current velocities at both sites were surprisingly high (Site e: $26.74 \mathrm{~cm} \mathrm{~s}^{-1}$, Site f: $24.97 \mathrm{~cm} \mathrm{~s}^{-1}$ ). The rest of the measuring period was characterized by slower current velocities (Site e: $\bar{x}=$ $5.49 \mathrm{~cm} \mathrm{~s}^{-1}, \mathrm{SD}=0.79$; Site f: $\bar{x}=6.01 \mathrm{~cm} \mathrm{~s}^{-1}, \mathrm{SD}=0.25$ ) and the erosion measured was almost nil (Site e: $\bar{x}=$ $0.027 \mathrm{~cm}, \mathrm{SD}=0.046$; Site $\mathrm{f}: \bar{x}=0.067 \mathrm{~cm}, \mathrm{SD}=0.072$ ).

\section{Superficial shell effect on sedimentary processes}

No significant differences were observed in the sediment level changes between shell-removal patches and controls (Mann-Whitney test: $Z=-0.73, \mathrm{n}=10, \mathrm{p}>$ $0.05)$, but the variance of the data was significantly higher in the treatment areas (Bartlett test: Bartlett

Table 6. Mean (SD) current velocity, density of surfacing life-position and loose shells, and erosion measurements for Sites e and $f$

\begin{tabular}{|c|c|c|c|}
\hline & Site e & Site $\mathrm{f}$ & $\mathrm{p}$ \\
\hline Current velocity $\left(\mathrm{cm} \mathrm{s}^{-1}\right)$ & $11.19(6.14)$ & $10.36(4.64)$ & $0.413^{a}$ \\
\hline Life-position shells (shells $\mathrm{m}^{-2}$ ) & $138.80(25.00)$ & $136.80(26.72)$ & $1^{b}$ \\
\hline Loose shells (shells $\mathrm{m}^{-2}$ ) & $223.00(37.10)$ & $47.00(25.80)$ & $<0.001^{b}$ \\
\hline Erosion (cm) & $0.40(0.23)$ & $1.01(0.51)$ & $0.003^{c}$ \\
\hline
\end{tabular}




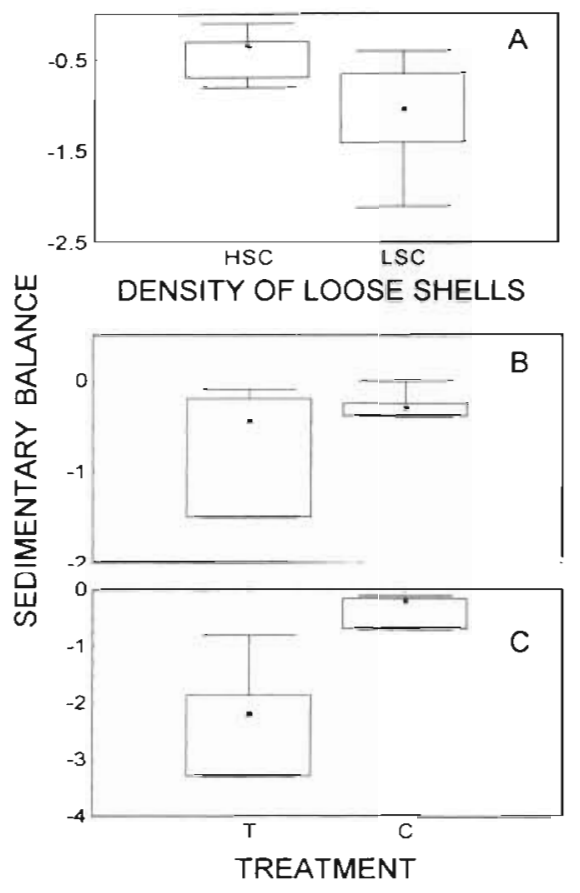

Fig. 7. Median quantile box plots comparing erosion measurements between (A) areas with contrasting density of loose shells, (B) shell removal and control areas, and (C) shell introduction and control areas; HSC: area with high loose shell density; LSC: area with low loose shell density; T: treatment;

$$
\text { C: control }
$$

chi-square $=5.01, \mathrm{df}=1, \mathrm{p}<0.05 ;$ Fig. 7B). Erosion in shell inclusion units was significantly higher than in control areas (Mann-Whitney test: $Z=-2.61, \mathrm{n}=10$, $\mathrm{p}<0.05$; Fig. 7C) Mean current velocity at Site $c$ was $24.62 \mathrm{~cm} \mathrm{~s}^{-1}(\mathrm{SD}=10.51)$.

\section{DISCUSSION}

The results of the samplings and experiments are in agreement with the predictions based upon the hypothesis that the habitat structural heterogeneity provided by surfacing life-position shells is positively influencing the abundance of benthic organisms. The number of species occurring at shell beds is higher than that registered in all other previously studied intertidal environments of the lagoon, where epifaunal organisms were shown to be scarce or absent (Gutiérrez et al. 1997, Bortolus et al. 1998, Botto et al. 1998). Higher densities of several infaunal taxa uccus in ine seament inside the shells, and similar inside-outside shell differences are promoted by the introduction of superficial life-position shells in a mud flat. This suggests that shell cavities offer better conditions for survival than the outside shell habitat. Moreover, surfacing life-position shells also affect the density of organisms in the sediment around them. Two surface-dwelling macroinfaunal species reduce in density after removal of lifeposition shells. The predator exclusion experiments demonstrate that shells protect the fauna inhabiting their cavity and the underlying infaund from predation and disturbance by big motile organisms. Lifeposition shells also affect the sedimentary balance and sediment grain size, which suggests that many of the encountered differences in the abundance of organisms may be mediated by sediment modification. In the following sections we discuss the mechanisms by which shells may be enhancing the abundance of several taxa.

\begin{tabular}{|c|c|c|c|c|c|}
\hline \multirow[t]{2}{*}{$\begin{array}{l}\text { PHYSICAL } \\
\text { STATE } 1 \\
\end{array}$} & \multicolumn{2}{|c|}{$\begin{array}{l}\text { PHYSICAL } \\
\text { STATE } 2\end{array}$} & \multicolumn{3}{|c|}{$\begin{array}{l}\text { POSSIBLE CONTROLS EXERTED ON RESOURCE } \\
\text { AVAILABILITY TO OTHER ORGANISMS }\end{array}$} \\
\hline & & & $\begin{array}{l}\text { CREATION OF } \\
\text { RESOURCES }\end{array}$ & $\begin{array}{l}\text { CONTROL OVER } \\
\text { ABIOTIC } \\
\text { RESOURCES }\end{array}$ & $\begin{array}{l}\text { MODULATION } \\
\text { OF ABIOTIC } \\
\text { FORCES }\end{array}$ \\
\hline $\begin{array}{l}\text { ALIVE } \\
\text { RAZOR } \\
\text { CLAMS }\end{array}$ & $\longrightarrow$ & $\begin{array}{l}\text { SEDIMENT } \\
\text { WITH } \\
\text { SHELLS }\end{array}$ & $\begin{array}{l}\text { Living space } \\
\text { Refuges } \\
\text { Hard substrata }\end{array}$ & $\begin{array}{l}\text { Sediment trapping } \\
\text { Nutrient capture }\end{array}$ & $\begin{array}{l}\text { Current impact } \\
\text { Relative humidity }\end{array}$ \\
\hline & $\begin{array}{c}\text { OYSTERCATCHER } \\
\text { PREDATION } \\
\text { AND EROSION }\end{array}$ & & & & \\
\hline
\end{tabular}

Fig. 8. Conceptual model explaining the physical ecosystem engineering carried out by oystercatchers preying on razor clams. Possible direct (creation and control of abiotic resources) and indirect controls on the availability of resources to other organisms (modulation of abiotic forces) are shown 


\section{Community composition}

Species richness in estuarine environments commonly appears to be positively correlated with habitat structural heterogeneity (e.g. Wilson 1979, Heck et al. 1989). In our bimonthly shell samplings, we found that $84.2 \%$ of the benthic macroinvertebrate species cited for the whole lagoon also occurred inside shells (see Orensanz \& Estivariz 1971, Olivier et al. 1972a, Spivak et al. 1994), and we added 4 species not previously recorded. The accumulation of shells in muddy areas has been proposed as a process that generates a hard substrate which promotes the development of an epifaunal community instead of the original infaunal community (Kidwell \& Aigner 1985), and increases the abundances of small macroinfauna, shallow burrowing organisms and species which use refuges (Kidwell 1986). The presence of typical rocky intertidal inhabitants such as the mytilid Brachidontes rodriguezii, the cirriped Balanus improvisus, and the gastropod Siphonaria lessoni (Bastida et al. 1971, Penchaszadeh 1973 ) could be evidence of these phenomena. In this study, $66.6 \%$ of the species encountered were epifaunal but the infaunal species were also numerically important. Further evidence is encountered in the fact that the most abundant species during the sampling period was a small shallow-burrowing amphipod, Corophium insidiosum, which is rarely found in the sediment of other intertidal environments of the lagoon (Gutiérrez et al. 1997).

\section{Protection from predation by shells and caging artifacts}

The not significant differences in the density of most species between cages and uncaged controls indicate that shells prevent predation and disturbance by big motile organisms on the fauna occurring inside shell cavities and in the underlying shell sediment. This result also indicates that the density of these species was not affected by caging artifacts. However, Heteromastus similis was found at lower densities inside cages in the 1997 experiment, which may be the result of caging artifacts. Although the sediments inside and outside cages were not compared, distinctive cageinduced changes in their characteristics (i.e. intensive siltation or sediment scouring beside the mesh; Hall et al. 1990, Raffaelli \& Hawkins 1996) were not noticeable. In addition, increased deposition of fine sediment rich in organic matter is likely to be advantageous to these deposit-feeding polychaetes (see Olivier et al. 1972b), which suggests that the opposite effect must occur. Therefore, this result could be explained by overpredation within the enclosure caused by small predators which may gain protection inside them (Hall et al. 1990). Nevertheless, there are no known small predators in the lagoon which feed on $H$. similis (Olivier et al. 1972b). In addition, this type of artifact is likely to be uncommon in intertidal studies, where most epibenthic predators are not normally present on tidal flats throughout the tidal cycle (Raffaelli \& Hawkins 1996).

\section{Abundance of macroinfauna and meiofauna inside and outside razor clam shells}

Despite the fact that large motile predators showed to have no effect on the abundance of benthic organisms at shell beds, the effect of environmental disturbances was not quantified in this study. Energetic water movement (such as storms) may kill or injure soft-bodied animals (Safriel \& Ben-Eliahu 1991), or erode the substrata surface modifying its granulometry and indirectly affecting the survival of the resident organisms (see Kneib 1991, Billick \& Case 1994). Moreover, we showed that razor clam beds are affected by erosive regimes. The higher abundance of several meiofaunal taxa and Corophium insidiosum in the internal, rather than in the external, shell sediment may be explained as a result of these processes. Infaunal amphipods (such as $C$. insidiosum) live close to the sediment-water interface (Day et al. 1989) and meiofauna are rarely encountered beyond the upper $3 \mathrm{~cm}$ depth in muddy areas (Sikora \& Sikora 1982). This pattern suggests that these organisms are more exposed in the case of a disturbance in the substrate surface. The internal shell sediment is possibly more stable due to the protection of the shells and thus it may be a more suitable habitat.

Alternatively, enhanced recruitment levels inside the shell cavity may occur. Substrate choice through active swimming has been suggested as the mode of meiofaunal recruitment in turbulent structurally complex environments after passive dispersal in the water column (Palmer 1988). On the other hand, passive deposition processes were found to be responsible for the high abundance and the particular pattern of distribution of meiofauna in fiddler crab burrows in a salt marsh habitat (DePatra \& Levin 1989). The active selection argument suggests that meiofauna suspended in the water column is able to settle in those habitats which offer better conditions for survival. In these terms, the refuge provided for the shells and their internal sediment which is rich in organic matter could be considered important resources. Taking into account the passive deposition explanation, shell cavities may behave as hydrodynamically quiet microhabitats trapping particles suspended in the turbulent water column over the shell assemblage, similar to 
burrows in mud-flats (e.g. DePatra \& Levin 1989, Iribarne et al. 1997). Both processes may explain the higher density of meiofauna and organic matter content occurring inside shells.

The higher densities of Corophium insidiosum found inside shells may also be the result of habitat selection. Higher densities for different Corophium species have been shown to be associated with specific sediment characteristics (e.g. Fenchel et al. 1975, Flach 1993). C. insidiosum acts facultatively as a suspension or deposit feeder (Miller 1984) and has an important ability of postsettlement dispersal by crawling or active swimming (Nair \& Anger 1979, pers. obs.). Benthic amphipods are able to emigrate in response to high predation or disturbance pressures (Ambrose 1984, Flach 1993), sedimentary and microtopographic characteristics (DeWitt 1987, Flach 1993) and food availability (DeWitt 1987). Lower predation pressures and higher organic matter content at the inner shell sediment suggests the possibility of habitat selection as the factor determining the highest $C$. insidiosum densities in the inner shell sediment.

\section{Effect of razor clam shells on the sediment community}

Response to shell removal

Shell removal decreases the abundance of at least 2 partially deposit-feeding species: Corophium insidiosum (Miller 1984) and Heteromastus similis (Olivier et al. $1972 \mathrm{~b}$ ). This decrease in density may be due to mortality caused by modifications in the structure or composition of the sedimentary environments (see Kneib 1991, Billick \& Case 1994). Although the sedimentary balance is strongly influenced by seasonal variations in sediment budgets (Gray 1981), our experiment demonstrates that shell removal may destabilize the sediment. Furthermore, an increment in the median grain size and a decrease in the silt-clay content of the sediment was observed in the shell removal patches, possibly by the erosion of the finest sediment fractions. This phenomenon probably affected the survival of deposit-feeding organisms or promoted their migration to more advantageous areas.

Despite the evidence indicating that shell removal negatively affect the densities of Corophium insidiosum and Heteromastus similis, probably through sediment destabilization and modification, other possibilities must be considered. Predation is one alternative explanation. Macroinfaunal species living near the sediment-water interface such as $H$. similis (see Botto et al. 1998) and C. insidiosum are highly susceptible to predation by motile surface predators. During the experimental period, flocks ranging between 20 and 80 two-banded plovers Charadrius falklandicus were observed feeding in the study area. Plovers possibly avoid feeding in patches with shell, preying heavily in shell-removal patches (see Quammen 1984, Gerritsen \& van Heezik 1985).

Another plausible explanation is that the recruitment of these species was affected by the presence of the shells. The turbulent flow caused by the substrate protruding structures may enhance passive larval recruitment (Eckman 1983). Sampling evidence supports this argument: shell removal affected 2 of the species that increased their abundances in the internal shell sedi-

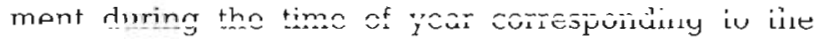
experimental period (Gutiérrez 1998). However, it is possible that the design of the experiment was not adequate enough to test this kind of effect because of hydrodynamic disturbance. When an obstruction occurs the equilibrium conditions are reached at approximately 25 times the height of the obstruction (see Nowell \& Jumars 1984). Thus, the size of our experimental units may not be large enough to avoid the effect of turbulent flow generated by the surrounding shells standing in life position and protruding from the sediment.

\section{Response to shell introduction}

The shell introduction experiment may provide indirect evidence of post-settlement mortality. The not significant differences obtained for juveniles of Laeonereis acuta and the significantly higher abundance of adult $L$. acuta in the inner shell sediment could be an indication that settlement by these species occurs approximately at the same magnitude in the shell cavities, surrounding sediment and unshelled sediment, but that post-settlement mortality is lower in the protected internal environment of the shells. Predation is one possible explanation. We demonstrate that shorebirds avoid probing inside the cavity of life-position shells. In addition, considering the location of the experimental area in the intertidal slope and the time of the year when the experiment was performed, mortality may also have been caused by the high summer temperatures (e.g. Hsieh \& Simon 1991). Water content was higher for the internal shell sediment than the external one, which indicates a reduced level of desiccation stress inside the shell cavities. Post-settlement migration is another possibility to explain these patterns. Settled polychaetes may migrate to areas with better conditions for survival (see Miron et al. 1991) such as, for example, the protected, wet, and organically rich internal shell sediment. 
The results obtained with ostracods, nematodes and Uca uruguayensis could be explained by differential mortality, and also by an increased settlement inside the shell cavities. The non significant differences in the harpacticoid copepod abundance between the shell sediment and the surrounding shells may indicate that the turbulence generated by protruding shells enhances settlement in the internal sediment as well as in the immediately surrounding substrate (see Eckman 1983). The presence of $U$. uruguayensis occupying shell cavities in this experiment and their absence in the shell samples taken from naturai beds can be explained by the intertidal height where the experimental units were installed. $U$. uruguayensis inhabits burrows in upper intertidal areas, adjacent to the surrounding Spartina densiflora salt marshes (Boschi 1964), while natural beds of superficial life-position razor clams are located at lower intertidal heights. The introduction of shells in the high intertidal area provides a structural element that may be adopted as refuge by $U$. uruguayensis.

\section{Positive effects and physical ecosystem engineering by oystercatchers}

The overall conclusion of this study is that superficial life-position Tagelus plebeius shells are positively affecting the abundance of organisms and richness of species. Positive interactions are not typically discussed as important community processes in the literature (Kareiva \& Bertness 1997) and have not been emphasized in studies of intertidal communities (Bertness \& Leonard 1997). Moreover, field manipulation experiments to understand the effects of physical ecosystem engineers are still uncommon (Bertness \& Leonard 1997, Jones et al. 1997). Ecosystem engineering may occur in 2 basic ways: (1) autogenic engineering, where the engineer is part of the new physical state (e.g. plant growth), and (2) allogenic engineering, where the engineer transforms materials from one physical state to another and is not necessarily part of the permanent physical structure of the ecosystem (e.g. construction of dams by beavers; Jones et al. 1997). In our study, clam mortality may be considered a case of allogenic ecosystem engineering. As was mentioned previously (see 'Introduction'), the formation of the horizon of Holocene life-position razor clams can be largely explained by a gradual and continuous predation by the American oystercatcher Haematopus palliatus (Iribarne et al. 1998) which results in the accumulation of life-position shells in the substrata. With the occurrence of erosive processes and the consequential surfacing of the shells, new resources are created and a control over different abiotic resources and forces is exerted (see Fig. 8). Thus, oystercatchers have long been engineering sediments by preying on razor clams. Organisms that engineer sediments (e.g. benthic bioturbators; Levinton 1995) tend to have large ecosystem level effects because sediments integrate many resources such as living space, nutrients and prey (Jones et al. 1997). Although the surfacing of the shells is a recent process considering the extent of the horizon, it could be predicted that oystercatcher engineering can have ecosystem-level effects that may last for long periods of time, even centuries or more (e.g. Jones et al. 1994). Moreover, this case may be evidence that the indirect effects of an interaction may be latent for a long period of time and expressed only when an auxiliary process occurs (i.e. erosion and surfacing of shells).

Acknowledgements. This project was supported by grants from Universidad Nacional de Mar del Plata (UNMDP) and CONICET (both to O.I.). E. Spivak, F. Isla and 4 anonymous reviewers provided useful comments about the manuscript. The results presented here are part of the J.G. thesis to obtain the Licentiate degree in Biology at the UNMDP.

\section{LITERATURE CITED}

Aliotta S, Farinatti EA (1990) Stratigraphy of Holocene sandshell ridges in the Bahía Blanca Estuary, Argentina. Mar Geol 94:353-360

Ambrose WG (1984) Increased emigration of the amphipod Rhepoxynius abronius (Barnard) and the polychaete Nephtys caeca (Fabricius) in the presence of invertebrate predators. J Exp Mar Biol Ecol 80:67-75

Bastida R, Capezzani A, Torti MR (1971) Fouling organisms in the port of Mar del Plata (Argentina). l: Siphonaria lessoni: ecological and biometric aspects. Mar Biol 10:297-307

Bertness MD, Leonard GH (1997) The role of positive interactions in communities: lessons from intertidal habitats. Ecology 78:1976-1989

Billick I, Case TJ (1994) Higher order interactions in ecological communities: what are they and how can they be detected? Ecology 75:1529-1543

Bortolus A, Iribame O. Martinez M (1998) Relationship between waterfowl and the seagrass Ruppia maritima in a southwestern Atlantic coastal lagoon. Estuaries 21 $710-71$ ?

Boschi EE (1964) Los crustáceos decápodos brachyura del litoral bonaerense (R. Argentina). Bol Inst Biol Mar Mar Del Plata 6:1-99

Botero L, Aterna J (1982) Behavior and substrata selection during larval settling in the lobster Homarus americanus. J Crustac Biol 21:59-69

Botto $F$, Iribarne OO, Martínez MM, Delhey $K$, Carrete M (1998) The effect of migratory shorebirds on the benthic species of three southwestern Atlantic Argentinean estuaries. Estuaries 21:700-709

Butman CA (1987) Larval settlement of soft-sediment invertebrates: the spatial scales of pattern explained by active habitat selection and the emerging role of hydrodynamic processes. Oceanogr Mar Biol Annu Rev 25:113-165

Connell JH (1961) The influence of interspecific competition 
and other factors on the distribution of the barnacle Chthamalus stellatus. Ecology 42:710-723

Conover WJ (1980) Practical nonparametric statistics, 2nd edn. John Wiley \& Sons, New York

Crisp DJ (1971) Energy flow measurements. In: Holme NA, McIntyre AD (eds) Methods for the study of marine benthos. IBP handbook no. 16. Blackwell Scientific Publications, Oxford, p 197-279

Dauer DM, Tourtellote GH, Ewing RM (1982) Oyster shells and artificial worm tubes: the roles of refuges in structuring benthic communities of the lower Chesapeake Bay. Int Rev Ges Hydrobiol 67:661-677

Day JW, Hall CAS, Kemp WM, Yañez Arancibia YA (1989) Estuarine ecology. John Wiley \& Sons, New York

DePatra KD, Levin LA (1989) Evidence of the passive deposition of meiofauna into fiddler crab burrows. J Exp Mar Biol Ecol 125:173-192

DeWitt TH (1987) Microhabitat selection and colonization rates of a benthic amphipod. Mar Ecol Prog Ser 36: $237-250$

Dumbauld BR, Armstrong DA, McDonald TL (1993) Use of oyster shell to enhance intertidal habitat and mitigate loss of Dungeness crab (Cancer magister) caused by dredging. Can J Fish Aquat Sci 50:381-390

Eckman JE (1983) Hydrodynamic processes affecting benthic recruitment. Limnol Oceanogr 28:241-257

Farinatti EA, Aliotta S, Ginsberg SS (1992) Mass mortality of a Holocene Tagelus plebeius population in the Bahía Blanca Estuary, Argentina. Mar Geol 106:301-308

Fasano JL, Hernández MA, Isla FI, Schnack EJ (1982) Aspectos evolutivos y ambientales de la laguna Mar Chiquita (provincia de Buenos Aires, Argentina). International Symposium on Coastal Lagoons, Bordeaux, France. September 8-14, 1981. Oceanol Acta (Suppl A):285-292

Fenchel T, Kofoed LH, Lappalainen A (1975) Particle size selection of two deposit feeders: the amphipod Corophium volutator and the prosobranch Hydrobia ulvae. Mar Biol 30:119-128

Fernandez M, Iribarne OO, Armstrong DA (1993) Habitat selection by young-of-the-year Dungeness crab Cancer magister and predation risk in intertidal habitats. Mar Ecol Prog Ser 92:171-177

Fernandez M, Iribarne OO, Armstrong DA (1994) Swimming behavior of Dungeness crab, Cancer magister Dana, megalopae in still and moving water. Estuaries 17:271-275

Flach EC (1993) The distribution of the amphipod Corophium arenarium in the Dutch Wadden Sea: relationships with the sediment composition and the presence of cockles and lugworms. Neth J Sea Res 31:281-290

Gerritsen AFC, van Heezik YM (1985) Substrate preference and substrate related foraging behaviour in three Calidris species. Neth J Zool 35:671-692

Gray JS (1981) The ecology of marine sediments. An introduction to the structure and function of benthic communities. Cambridge University Press, Cambridge

Gutiérrez JL (1998) Rol de los depósitos holocenos de la almeja navaja Tagelus plebeius en la estructuración de comunidades bentónicas actuales. Thesis, Universidad Nacional de Mar del Plata

Gutiérrez JL, Schwindt E, Palomo MG, Botto F, Bortolus A (1997) Abundance relationships between macroinfauna and meiofauna in five different environments of a SW Atlantic lagoon. In: VII Congreso Latinoamericano de Ciencias del Mar, Santos, p 406-408 (extended abstract)

Hall SJ, Raffaelli DG, Turrel WR (1990) Predator-caging experiments in marine systems: a reexamination of their value. Am Nat 136:657-672
Hannan CA (1984) Planktonic larvae may act as passive particles in turbulent near-bottom flows. Limnol Oceanogr 29:1108-1116

Heck KL, Able KW, Fahay MP, Roman CT (1989) Fishes and decapod crustaceans of Cape Cod eelgrass meadows: species composition, seasonal abundance patterns and comparison with unvegetated substrates. Estuaries 12:59-65

Hernkind WF, Butler MJ (1986) Factors regulating postlarval settlement and juvenile microhabitat use by spiny lobsters Panulirus argus. Mar Ecol Prog Ser 34:23-30

Holland AF, Dean J (1977a) The biology of the stout razor clam Tagelus plebeius. 1 Animal-sediment relationships, feeding mechanism and community biology. Chesapeake Sci 18:58-66

Holland AF, Dean J (1977b) The biology of the stout razor clam Tagelus plebeius. 2. Some aspects of the population

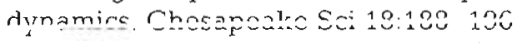

Hsieh HL, Simon JL (1991) Effects of temperature on the breeding of Kinbergonuphis simoni (Polychaeta: Onuphidae). Bull Mar Sci 48:469-476

Iribarne OO, Botto $F(1998)$ Orientation of the extant stout razor clam Tagelus plebeius in relation to current direction: its palaeoecologic implications. J Shellfish Res 17 : $165-168$

Iribarne OO, Bortolus A, Botto F (1997) Between-habitat differences in burrow characteristics and trophic modes in the southwestern Atlantic burrowing crab Chasmagnathus granulata. Mar Ecol Prog Ser 155:137-145

Iribarne OO, Armstrong DA, Palacios R, Fernandez M (1992) Ecological effects of adding bivalve shell to intertidal softbottom areas. Northwest Environ J 8:153-154

Iribarne OO, Valero JL, Martínez MM, Lucifora LO, Bachmann S (1998) Shorebird predation may explain the origin of SW Atlantic Holocene life-position stout razor clams. Mar Ecol Prog Ser 167:301-306

Isla FI, Rivero D'Andrea I (1993) Procesos retrotafonómicos en secuencias de aguas someras. Pesquisas (Porto Alegre, Brazil) 20:90-95

Jones CG, Lawton JH, Shachak M (1994) Organisms as ecosystems engineers. Oikos 69:373-386

Jones CG, Lawton JH, Shachak M (1997) Positive and negative effects of organisms as physical engineers. Ecology $78: 1946-1957$

Kareiva PM, Bertness MD (1997) Re-examining the role of positive interactions in communities. Ecology 78:1945

Kidwell SM (1986) Taphonomic feedback in Miocene assemblages: testing the role of bed hardparts in benthic communities. Palaios 1:239-255

Kidwell SM, Aigner T (1985) Sedimentary dynamics of complex shell beds: implications for ecological and evolutionary patterns. In: Bayer U, Seilacher A (eds) Sedimentary and evolutionary cycles. Springer Verlag. Berlin, p 382-395

Kneib RT (1984) Patterns of invertebrate distribution and abundance in the intertidal salt marsh: causes and questions. Estuaries 7:392-412

Kneib RT (1991) Indirect effects in experimental studies of marine soft sediment communities. Am Zool 31:874-885

Lanfredi NW, Balestrini CF, Mazio CA, Schmidt SA (1987) Tidal sandbanks in Mar Chiquita coastal lagoon, Argentina. J Coastal Res 3:515-520

Lawton JH, Jones CG (1995) Linking species and ecosystems: organisms as ecosystems engineers. In: Jones CG, Lawton $\mathrm{JH}$ (eds) Linking species and ecosystems. Chapman \& Hall, New York, p 141-150

Lenihan HS, Peterson $\mathrm{CH}$ (1998) How habitat degradation through fishery disturbance enhances impacts of hypoxia on oyster reefs. Ecol Appl 8:128-140 
Levinton J (1995) Bioturbators as ecosystem engineers: control of the sediment fabric, inter-individual interactions, and material fluxes. In: Jones CG, Lawton JH (eds) Linking species and ecosystems. Chapman \& Hall, New York p 29-36

Ludwig JA, Reynolds JF (1988) Statistical ecology: a primer on methods and computing. John Wiley \& Sons, New York

Manly BFJ (1992) The design and analysis of research studies. Cambridge University Press, Cambridge

Meyer DL, Townsend EC, Thayer GW (1997) Stabilization and erosion control value of oyster cultch for intertidal marsh. Restoration Ecol 5:93-99

Miller DC (1984) Mechanical post-capture particle selection by suspension and deposit-feeding Corophium. J Exp Mar Biol Ecol 82:59-76

Miron G, Desrosiers G, Retière C, Lambert R (1991) Dispersion and prospecting behavior of the polychaete Nereis virens (Sars) as a function of density. J Exp Mar Biol Ecol $145: 65-77$

Nair KKC, Anger K (1979) Life history of Corophium insidiosum (Crustacea, Amphipoda) in laboratory culture. Helgol Wiss Meeresunters 32:279-294

Narosky T, Izurieta D (1993) Guía para la identificación de las aves de Argentina y Uruguay, Vazquez-Mazzini Editores, Buenos Aires

Nowell A.RM, Jumars PA (1984) Flow environments of aquatic benthos. Annu Rev Ecol Syst 15:303-328

Olivier SR, Escofet A, Penchazadeh P, Orensanz JM (1972a) Estudios ecológicos de la región estuarial de Mar Chiquita (Buenos Aires, Argentina), I. Las comunidades bentónicas. An Soc Cient Argent 193:237-262

Olivier SR, Escofet A, Penchazadeh P, Orensanz JM (1972b) Estudios ecológicos de la región estuarial de Mar Chiquita (Buenos Aires, Argentina), II. Relaciones tróficas interespecíficas. An Soc Cient Argent 194:89-104

Orensanz JM, Estivariz MC (1971) Los anélidos poliquetos de aguas salobres de la provincia de Buenos Aires. Rev Mus La Plata 11:95-104

Paine RT (1966) Food web complexity and species diversity Am Nat 100:65-75

Palmer MA (1988) Dispersal of marine meiofauna: a review and conceptual model explaining passive transport and active emergence with implications for recruitment. Mar Ecol Prog Ser 48:81-91

Penchaszadeh PE (1973) Ecología de la comunidad del mejillín Brachydontes rodriguezii en el mediolitoral rocoso de Mar del Plata. El proceso de colonización. Physis (B Aires) $32: 51-54$

Peterson CH (1979) Predation, competitive exclusion and diversity in the soft-sediment benthic communities of estu-

Editorial responsibility: Otto Kinne (Editor). Oldendorf/Luhe, Germany aries and lagoons. In: Livingston RJ (ed) Ecological processes in coastal and marine systems. Plenum Press, New York

Peterson CH (1982) Clam predation by whelks (Busycon spp.): experimental tests on the importance of prey size, prey density, and seagrass cover. Mar Biol 66:159-170

Peterson CH (1986) Enhancement of Mercenaria mercenaria densities in seagrass beds: is pattern fixed during settlement season or altered by subsequent differential survival? Limnol Oceanogr 31:200-205

Quammen ML (1984) Predation by shorebirds, fish, and crabs on invertebrates in intertidal mudflats: an experimental test. Ecology 65:529-537

Raffaeli DG, Hawkins S (1996) Intertidal ecology. Chapman \& Hall, London

Rhoads DC, Mc Call PL, Yingst JY (1978) Disturbance and production on the marine seafloor. Am Sci 66:577-587

Safriel UN, Ben-Eliahu MN (1991) The influence of habitat structure and environmental stability on the species diversity of polychaetes in vermetid reefs. In: Bell SS, McCoy ED, Mushinsky HR (eds) Habitat complexity: the physical arrangement of objects in space. Chapman \& Hall, New Y̌ork, p 349-372

Schnack EJ, Fasano JL, Isla FI (1982) The evolution of the Mar Chiquita Lagoon, province of Buenos Aires, Argentina. In: Colquhoun DJ (ed) Holocene sea level fluctuations: magnitudes and causes. IGCP 61, Univ. S. Carolina, Columbia, $\mathrm{SC}, \mathrm{p} 143-155$

Sikora W, Sikora J (1982) Ecological implications of the vertical distribution of meiofauna in salt marsh sediments. In: Kennedy V (ed) Estuarine comparisons. Academic Press, New York, p 269-282

Spivak E, Anger K, Luppi T, Bas C, Ismael D (1994) Distribution and habitat preferences of two grapsid crab species in Mar Chiquita Lagoon (Province of Buenos Aires, Argentina). Helgol Meeresunters 48:59-78

Underwood AJ (1997) Experiments in ecology. Their logical design and interpretation using analysis of variance. Cambridge University Press, Cambridge

Wilson WH (1979) Community structure and species diversity of the sedimentary reefs constructed by Petaloproctus socialis (Polychaeta: Maldanidae). J Mar Res 37:623-641

Woodin SA (1981) Disturbance and community structure in a shallow water sand flat. Ecology 62:1052-1066

Woodin SA (1985) Effects of defecation by arenicolid polychaete adults on spionid polychaete juveniles in field experiments: selective settlement or differential mortality J Exp Mar Biol Ecol 87:119-132

Zar JH (1984) Biostatistical analysis. Prentice-Hall, Englewood Cliffs, NJ

Submitted: May 6, 1998; Accepted: March 2, 1999

Proofs received from author(s): August 5, 1999 